\title{
Stem Cell Transplantation and Medical Tourism at Ankara Oncology Training and Research Hospital
}

\section{Ankara Onkoloji Eğitim ve Araştırma Hastanesi'nde Kök Hücre Nakli ve Medikal Turizm}

Derya Şahin ${ }^{1}$, Tuğçe Nur Yiğenoğlu ${ }^{1}$, Semih Başc1 ${ }^{1}$, Bahar Uncu Ulu ${ }^{1}$, Tahir Darçın ${ }^{1}$, Mehmet Bakırtaş ${ }^{1}$, Jale Yıldız ${ }^{1}$, Alparslan Merdin ${ }^{1}$, DİCLE İSKENDER ${ }^{1}$, Merih Kızıl Çakar ${ }^{1}$, MEHMET SINAN DAL ${ }^{1}$, Fevzi Altuntaş²

${ }^{1}$ Hematoloji ve Kemik İliği Nakli Merkezi, Ankara Dr. Abdurrahman Yurtaslan Onkoloji Eğitim ve Araştırma Hastanesi, Sağlık Bilimleri Üniversitesi, Ankara

${ }^{2}$ Yıldırım Beyazıt Üniversitesi, İç Hastalıkları ve Hematoloji Anabilim Dalı, Ankara, Türkiye

\section{ÖZET}

GİRIŞ ve AMAÇ: Medikal turist tanımı çeşitli tıbbi tedavi türlerini almak için uluslararası sınırlar arasında seyahat etmeyi seçen demektir. Hizmetin kalitesi ve kullanılabilirliği, tıp turizmi davranışının yanı sıra ekonomik ve kültürel faktörleri de etkiler. Birçok ülke, medikal turizm tarafından sağlanan firsatlardan yararlanmanın yollarını araştırmaya başladı. Ülkemizde sağlık turizmi hastaları genellikle özel hastanelerde tedavi edilmektedir. Sağlık turizmi hastalarının devlet hastanelerinde kabulü, ülke ekonomisine katkıda bulunacaktır. Bu çalışmanın amac1, hastanemiz hematoloji kliniğinin kemik iliği naklinde sağlık turizmi potansiyeline dikkat çekmek.

YÖNTEM ve GEREÇLER: Ankara Onkoloji Hastanesi'nde 2009-2019 yılları arasında sağlık turizmi ve iki taraflı anlaşma kapsamında yapılan kemik iliği nakillerinin sayısal analizi yapıldı.

BULGULAR: Geçtiğimiz on yılda merkezimizde 33 hastada otolog transplantasyon, 37 hastada allojeneik kemik iliği transplantasyonu yapıldı.

TARTIŞMA ve SONUÇ: Tecrübeli kemik iliği nakil merkezlerinde sağlık turizmi, yakındaki coğrafyadaki ülkelerden hastaları çekerek ülke ekonomisine katkıda bulunabilir.

Anahtar Kelimeler: Medikal turizm, kök hücre nakli, ulusal ekonomi

\begin{abstract}
INTRODUCTION: Medical tourists select to travel across international borders to receive various kinds of medical treatment. The quality and availability of the service also affects the behavior of medical tourism, as well as economic and cultural factors. Many countries started to investigate the ways to benefit from the opportunities provided by the medical tourism. In our country, health tourism patients are generally treated in private hospitals. The acceptance of health tourism patients in public hospitals will contribute to the national economy. The aim of this study is to draw attention to the health tourism potential of bone marrow transplantation of our hematology clinic.

METHODS: Quantitative analysis of bone marrow transplants performed in Ankara Oncology Hospital between 2009-2019 under the scope of health tourism and bilateral agreement was performed. RESULTS: In the last decade, 33 patients underwent autologous transplantation and 37 patients underwent allogenic bone marrow transplantation in our clinic.

DISCUSSION AND CONCLUSION: Health tourism in experienced bone marrow transplant centers can contribute to the country's economy by attracting patients from countries in the nearby geography.

Keywords: Medical tourism, stem $\quad$ cell transplant, national economy
\end{abstract}

\section{INTRODUCTION}

Medical tourism can be defined as the process of traveling outside the country of residence for the purpose of receiving medical care. Originally, the term referred to the travel of patients from less-developed countries to developed nations in pursuit of the treatments not available in their homeland (1). The main factors leading people in medical tourism are various such as high treatment costs, long waiting queue for treatment or lack of insurance in their own country (2). The Hematopoietic Stem Cell Transplantation (HSCT), formerly known as bone marrow 
transplantation, is a general term for various procedures in which the patient is treated with infusion of hematopoietic progenitor cells following chemotherapy and / or radiation therapy. HSCT can be typed according to the hematopoietic cell donor, the source of hematopoietic progenitor cells and the preparation regimen. Autologous HSCT is a type of hematopoietic progenitor cells collected from the patient prior to administration of high-dose chemotherapy to treat an underlying malignancy. Allogeneic HSCT refers to the use of hematopoietic progenitor cells collected from a healthy donor. The source of hematopoietic progenitor cells is usually peripheral blood and also can be obtained by cord blood or bone marrow harvest. Dr. Abdurrahman Yurtaslan Oncology Training and Research Hospital is one of Turkey's most important stem cell transplant centers. In the last decade, nearly a thousand stem cell transplants were performed. Medical tourism experiences in the stem cell transplant unit of Ankara Oncology Training and Research Hospital will be discussed in this article.

\section{MATERIAL and METHODS}

A total of 830 hematopoietic transplant patients at Dr.Abdurrahman Yurtaslan Ankara Oncology Training and Research Hospital between December 2009 and December 2018 were retrospectively analyzed. 498 (\%60) were autologous transplants and 332 (\%40) were allogeneic transplants. Indications of transplants within autologus transplants and allogeneic transplants in local and health tourism patients were investigated.

IBM SPSS Statistics (version 21) was used for statistical analysis and graphics. Descriptive statistics were used to summarize the data. Categorical data were expressed as a ratio, and numerical data were expressed as median and mean \pm standard deviation. Overall survival was evaluated by Kaplan-Meier test, and the difference between groups was evaluated by log-rank test. $\mathrm{P}<0.05$ was considered significant.

\section{RESULTS}

Since 2010, foreign patients are treated in our hospital and stem cell transplantations are

Adress for correspondence: Uzm. Dr. Derya Şahin Mehmet Akif Ersoy Mahallesi, 13. Cadde, No: 56, Ankara Onkoloji Hastanesi, Urankent Ek Bina 1. Kat 06200 ANKARA - Türkiye e-mail: dr.deryasahin@ hotmail.com

Available at www.actaoncologicaturcica.com

Copyright $($ Ankara Onkoloji Hastanesi

performed. These patients are mostly from the Balkan countries, Kazakhstan, Kyrgyzstan, Azerbaijan and some African countries. A total of 37 allogenic and 34 autologous stem cell transplants were performed in our hospital within the scope of medical tourism. The highest rate of allogeneic HSCT among medical tourism patients belongs to those diagnosed with acute myeloblastic leukemia (AML) $(43.2 \%)$ and acute lymphoblastic leukemia ALL (29.7\%) (figure 1). Four of the 38 allogeneic transplant patients were lost in the post-transplant period, two of whom were diagnosed with severe aplastic anemia, two with high-risk AML. Main indications for autologous transplantation were multiple myeloma (39.4\%), hodgkin lymphoma (36.4\%), and non-hodgkin lymphoma (24.2\%)(figure2). In our center, 37 of 369 allogeneic transplants and 33 of 531 autologous transplant were carried out within the scope of medical tourism (figure 3). The overall survival was $80.6 \pm 2.6$ in Turkish citizens and $67.6 \pm 10.7$ in health tourism patients with autologus HSCT(table 1). The overall survival was $63,68 \pm 3.29$ in Turkish citizens and $43.11 \pm 4.55$ in health tourism patients with allogeneic HSCT(table 2). There was no significant difference between the survival rates of health tourism patients and Turkish citizens in both autologous HSCT(p:0.73) and allgenic HSCT(p:0.07).

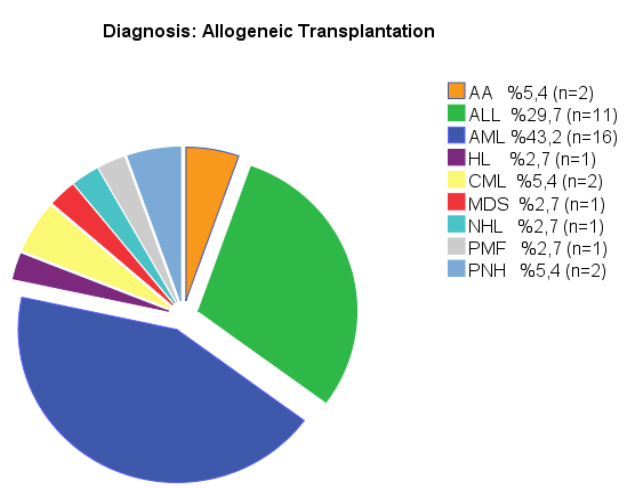

AA: aplastic anemia, ALL: acute lymphoblastic lymphoma, AML: acute myeloid leukemia, HL: hodgkin lymphoma, CML: chronic myeloid leukemia, MDS: myelodysplastic sendrom, NHL: non-hodgkin lymphoma, PMF: primary myelofibrosis, PNH: paroxysmal nocturnal hemoglobinuria.

Figure 1: Indications of Allogeneic Transplants for Medical Tourism Patients 


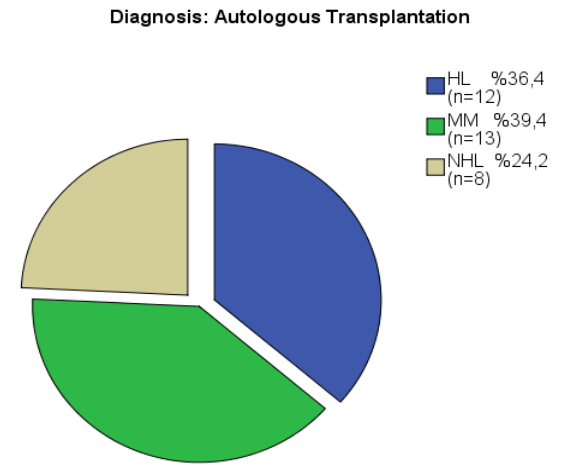

HL: hodgkin lenfoma, NHL: non-hodgkin lenfoma, MM: multipl myeloma

Figure 2: Indications of Autologous Transplants for Medical Tourism Patients

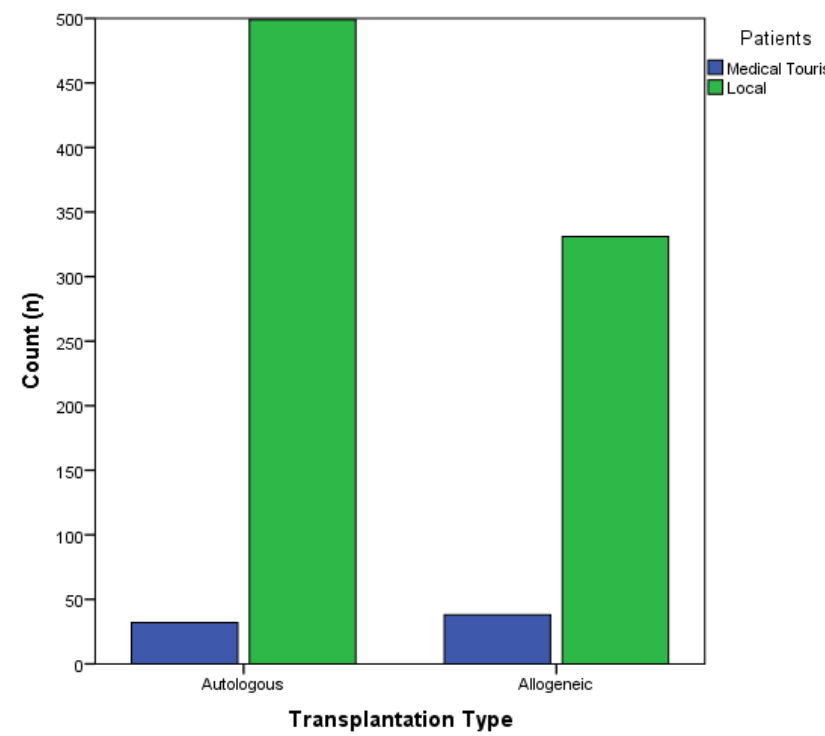

Figure 3: Autologus Transplants: Medical Tourism Patients (n):33, Local patients (n): =498 Allogeneic Transplants: Medical Tourism Patients (n):37, Local patients (n): $=332$

Table 1: Overal Survival for Turkish citizens vs Health tourism patients with Autologous BMT

\begin{tabular}{|c|c|c|}
\hline Patients & $\begin{array}{l}\text { Overall } \\
\text { survival }\end{array}$ & $P$ value \\
\hline $\begin{array}{l}\text { Turkish } \\
\text { citizens }\end{array}$ & $80,6 \pm 2,6$ & \multirow[t]{2}{*}{0,73} \\
\hline $\begin{array}{l}\text { Health } \\
\text { Tourism } \\
\text { patients }\end{array}$ & $67,6 \pm 10,7$ & \\
\hline
\end{tabular}

Table 2: Overal Survival for Turkish citizens vs Health tourism patients with Allogeneic BMT

\begin{tabular}{|c|c|c|}
\hline Patients & $\begin{array}{l}\text { Overall } \\
\text { survival }\end{array}$ & $P$ value \\
\hline $\begin{array}{l}\text { Turkish } \\
\text { citizens }\end{array}$ & $63,68 \pm 3.29$ & \multirow[t]{2}{*}{0,07} \\
\hline $\begin{array}{l}\text { Health } \\
\text { Tourism } \\
\text { patients }\end{array}$ & $43.11 \pm 4.55$ & \\
\hline
\end{tabular}

\section{CONCLUSION}

In Turkey, medical tourism has rapidly developed in the last decade (3-5). Forty-nine health care institutions have been accredited by the Joint Commission International (JCI) in Turkey (6). According to data reported by the Ministry of Health of Turkey, medical tourism ranks 14th in the Index $(7,8)$. The most preferred cities were Antalya and Istanbul. Private hospitals were preferred by $91 \%$ of medical tourists, where as government hospitals and university hospitals only received 9\% of the medical tourists. Most of the medical tourists were from Libya, Germany, and Iraq. The Turkish Ministry of Health has made mutual agreements on health with countries including Sudan, Afghanistan, Yemen, Albania, Azerbaijan, and Bahrain (9).

Private health insurance is not widespread in Turkey, a health insurance system covering all areas of cancer treatment is available to the citizens. The treatment of cancer is quite expensive. In recent years, training and research hospitals have been expropriated under the name of Health Sciences University and their staff has been strengthened academically. The old state hospital buildings are replaced by city hospitals equipped with the latest technology and high patient comfort. Generally, medical tourism patients prefer private patient care centers because they are more comfortable. With the advantage of widespread city hospitals, more medical tourism patients could be treated in public hospitals. In addition, treatment of medical tourism patients in public hospitals will contribute to the national economy.

\section{REFERENCES}




\section{Orginal Article}

1. Ramirez de Arellano AB. Patients with out borders: the emergence of medical tourism. Int J Health Serv. 2007;37(1):193-198. doi:10.2190/4857-468g-2325-47uu.

2. 10. Morciano $C$, Laricchiuta $P$, Taruscio $D$, Schunemann H. European Reference Networks and Guideline Development and Use: Challenges and Opportunities. Public Health Genomics. 2015;18(5):318-320. doi:10.1159/000435852.

3. De Neve JW, Dave R, Gurel M, Subramanian SV. International patients in a Turkish hospital: a quantitative study on cross-border health care at the intersection of Eastern Europe, Asia and the Middle East. World Hosp Health Serv. 2012;48(1):5-7.

4. Ucak H. The relationship between the growth in the health sector and in bound health tourism: the case of Turkey. Springer plus. 2016;5(1):1685. doi:10.1186/s40064-016-33418 .
5. Ozan-Rafferty ME, Johnson JA, Shah GH, Kursun A. In the words of the medical tourist: an analysis of Internet narratives by health travelers to Turkey. J Med Internet Res. 2014;16(2):e43. doi:10.2196/jmir.2694.

6. Wood head A. Scoping medical tourism and international hospital accreditation growth. Int $\mathbf{J}$ Health Care Qual Assur. 2013;26(8):688- 702. doi:10.1108/ijhcqa-10-2011-0060.

7. Fetscherin M, Stephano RM. The medical tourism index: Scale development and validation. Tour Manag. 2016;52:539-556. doi:10.1016/j.tourman.2015.08.010.

8. Republic of Turkey, Ministry of Health, Directorate general of Health Services, Department of health tourism. Evaluation Report on Medical Tourism in Turkey. Ankara: Ministry of Health; 2013.

9. Lunt N, Horsefall D, Hanefeld J. Handbook on Medical Tourism and Patient Mobility. Northampton, MA: Edward Elgar Publishing Ltd; 2015. doi:10.4337/9781783471195. 